\title{
School Administrators and Generation Z Students' Perspectives for a Better Educational Setting
}

\author{
Münevver Çetin ${ }^{1}$, Meral Halisdemir ${ }^{2}$ \\ ${ }^{1}$ Department of Educational Sciences, Marmara University, Istanbul, Turkey \\ ${ }^{2}$ Tecaher, İstanbul,Turkey \\ Correspondence: Munevver Çetin’ Department of Educational Sciences, Marmara University, Istanbul, Turkey.
}

Received: November 19, 2018

Accepted: December 17, 2018 Online Published: January 3, 2019

doi:10.11114/jets.v7i2.3773

URL: https://doi.org/10.11114/jets.v7i2.3773

\begin{abstract}
The purpose of this study is to examine the school administrators and Generation Z's perspectives towards each other. The conflict between school administrators and the emerging generation has always been a hot-debate research topic, and it is undeniable that each generation with new defining characteristics make this subject to be worthwhile to re-consider and re-discuss. For this research, from various schools in Istanbul, Kadikoy province, 15 different school administrators and 20 different students of $Z$ generation which were born 2000 and after were volunteered to participate to the research group. This study employed phenomenology pattern and semi- structured negotiation for data collection, and the analysis of the data has been done by using NVIVO 10 program. The study revealed that there are numerous factors that affect the school administrator's lives: new demands and challenges emerging with new generation, the adaptation problem to the modern instructional technologies and computer-aided teaching system, the role ambiguity, parent's approach and outside relations influence quality and school management adversely. On the other hand, the analysis of Generation Z student's perspective brings up a new perspective to the issue of generation gap. From their perspective, the school administrators fail to act in accordance with the changing time and its demands. Most important of all, the generation gap causes the problem of communication, empathy and identification, and this has a decisive, particularly negative influence on their perspective of school life and school administrators. In this study, expectations, responses and critical insights are examined from the lenses of school administrators and students in a way to provide recommendations that could be remedy for the concerns of the school administrators and Generation $\mathrm{Z}$ students not only in theory but also in practice.
\end{abstract}

Keywords: challenges, generation z, perspectives, school administrators, solutions

\section{Introduction}

Time and evolution bring the specific and distinctive characteristics of each generation together. Today's generation is different from the previous generation as they have the ability to control all the technological devices and they contact with their peers through the information and communication technologies. Nowadays, the older generation is astonished to see that the new generation literally turns deeply-seated values of the older generation grew up with upside down. The major part of the conflicts experienced in the schools arises from the generation gap among students with different ages. Generation Z, who are raised with the new educational system, acts unusually in school settings. The new profile of students causes confusion from time to time. In such a new setting, education administrators who have grown up in the traditional system encounter with many unfamiliar problems.

This study starts with a brief literature on Generation Z students. After presenting the procedures of the qualitative method used in the study, themes and sub themes were revealed with selected quotations and anecdotes. This is a unique study in which the voices of school administrators and Generation $\mathrm{Z}$ students' voices are heard throughout the paper.

\subsection{The Notion of Generation}

Generation' is the word used to describe the members of a community who are born in the same period, responsible for similar tasks, and experience similar situations and also difficulties (TDK, 2015). The term "jenerasyon" that we use in 
Turkish is originally derived from the word root "generire" meaning "to create" in Latin, or "generation" which means "ancestry", "lineage" in French (Oral, 2013).

Generational experiences affect the generation's perfective toward the world integrating the values and the cults (Pacis et al., 2012). The individuals belonging to the same generation react same to the similar situations, identify themselves as the members of the same group and consider the others as different. According to individuals shared things are not just the years but more (Cetin-Aydin and Basol, 2014). It is claimed that the people, who have brought up in depressing years, learnt the skills like economic determinism, rationalism, materialism, and respect for authority whereas the ones, who have been brought up in the years when there is socio-economic stabilization, embraced some post-modern values, such as; egalitarianism, tolerance to the differences and sharing (Gürbüz, 2015).

As discussed above, the historical limitation of the generations differs in literature. In this study, the timeline for each generations' origin are discussed as follows:

- The Traditional Generation: 1922-1943

- The Baby Boomers: 1944-1964

- Generation X: 1965-1977

- Generation Y: 1978-1994

- Generation Z: 1995 and today (Pacis et al., 2012)

The Traditional Generation, also known as "The Silents", whose members were born during the Great Depression and experienced the challenges during World War II, has prudent, cautious, frugal and hard-working disposition due to economical and political instability (Demirkaya, Akdemir, Karaman, and Atan, 2015). Those people, the eldest members of our society shows excessive obedience to the authority, and have a tendency to comply with stability and order (Adiguzel, Batur, and Eksili, 2014). The generation born between the end of World War II and 1964 is called Baby Boomers Generation. The generation born after the war times and had the capability of changing the world over again. These individuals, also challengers, question the traditions of the old generation (Guthrie, 2009). Baby Boomers suppose that new generations need their time-honored experience and knowledge (Saleh, 2009).

The individuals born between 1965 and 1977 are defined as Generation X. The members of Generation X are the children of Baby Boomers, grown up with financial, family and societal insecurity (Tolbize, 2008). The invention of the television has changed many habits. Technology has gradually started to take place in house and workplace; however, it is too challenging to acquire it for Generation X, who are in the first step of digital evolution (Gutherie et al., 2009). The parents of the generation, following the Baby Boomers and also called Baby Buster, had to work to meet their needs and were known as self-sufficient individuals. The Generation X, the children of the fragmented families, are called as 'Laych-key children', who go to school and return home alone and get into the house taking the key under the doormat (Quinn, 2010).

The individuals born between (1980-1999 are defined as Y Generation. Born in 1980 Generation Y was named after the question word "Why" due to their trait of being interrogators (Oral, 2013). In millennium, they had many different names, the ones commonly known are 'Millennials', 'Net Gen', 'Gen Y', 'I-Gen', or 'Digital Natives' (Skene, Cluett and Hogan, 2007). There have been some certain changes in education with Generation Y telling opinions freely, honest, self-confident and assertive. According to the surveys, Generation Y appreciates learning in the workplace (Schofield and Honere, 2010). Particularly, due to being specialized in using the internet, they possess multiple identities. By replacing the real world perception with the virtual world, the virtual world of the internet has led people's to build their self and relationships with the symbols offered by the virtual world, and has created a break in the perception of the world based on production, and becomes the first generation that paves the way for consumerist world order. The Generation Y is good at both using and creating technology (Yucebalkan and Aksu, 2013).

Born in and after 2000s, the Generation, who is still studying or the oldest ones are at high school age is called Generation Z. The generation is called 'Gen I', 'Net Generation', 'Next Generation', 'Instant Online', 'iGen', or '.com Generation' since they were born in the age when the technological developments are fast (Oral, 2013). The students of the generation, known also as 'babies born with a chip' is the most unmotivated, uninterested, disconnected, yet active ones with technology. While taking notes on the computer in class, they are also able to send instant messages to their friends, surf on the net, and read 'The Color Purple' at the same time. The technology developed recently has had such a tremendous influence on them that is incomparable to the previous ones. This generation has been growing up in a world where various media tools and networks, such as, the internet, PC/Mac, video games, Facebook, MySpace, Twitter, Flickr, Skype, iPod, iPhone, PDA, and the remote control of TV/DVD are available, and they can carry these electronic devices on them anywhere, and in their view, they are irreplaceable for them (Berk, 2009). Many of them have never seen a camera whose photographic films are sent to photo print. Instead, they have their cellphones and 
social media accounts where photographs can be saved and shared instantly. Generation Z has a wireless, super-fast, user-controlled world where they are just a click away from the information. Also, this generation has been growing up with fewer siblings than older generations. As a natural consequence of the reduction in size of the families, the family members are able to provide their children with more attention, affection and pocket money, which give rise to excessive individualism and ego-centrism. Therefore, it would not be wrong to draw the conclusion that the notions like reconciliation, teamwork or sharing are things they are unfamiliar with and less likely to perform in their daily lives. As soon as they are born, they are brought up as princesses or princes of their parents, and therefore; as the phrase goes, the children of Generation $Z$ are brought up 'wrapped in cotton wool'; unaware of the challenges of the life (Mc Queen, 2011). Since Generation $Z$ has risen up to the world of technology, they develop different characteristic traits compared to the previous generation. The common characteristic traits of Generation $\mathrm{Z}$ tech-savvy can be defined as follows: using web search engines to get information, being internet content creator, engaging in multimedia and visual materials (not a book reader, but interested in graphics, videos, games or photographs), learning by trial and error, expecting feedback while learning, being able to perform multiple tasks, being goal-oriented individuals, choosing typing rather than handwriting, being able to interact with elderly people and the figures of authority (parents, teachers) comfortably, having emotional transparency, expressing their feelings without hesitation (Berk, 2009).

The characteristics of Generation $\mathrm{Z}$ are favorable and advantageous, yet our education system is unable to keep up with the technological developments. This situation is verified by the failure in The Programme for International Student Assessment (PISA) tests and employment deficiency shows that our education system needs to be revised to be compatible with the requirements of Generation $\mathrm{Z}$. To maintain the welfare and progress of the country, it is crucially important to have Generation $\mathrm{Z}$ participate in the human resources pool of our country dynamically because they are risk takers, creative, and do not accept the current circumstances and data of the country as it is (Ulker, 2013).

Today, the students of Generation $\mathrm{Z}$ gather at the same schools with school administrators belonging either to Generation $\mathrm{Y}$ and Generation $\mathrm{Z}$, who prepare them for the future. The major part of the problems encountered at schools is caused by the generation gap among these three generations. To proceed a successful educational process and create an integrated school culture, school administrators should examine the strengths and weaknesses of each generation and take the possible measurements. In order to succeed this educational utopia comprised of successful school management and harmony between generations, it is essential to know the characteristics of the each generation and their perspectives toward one another. Therefore, in the light of the argument above, this study primarily examines the views of school administrators toward Generation $\mathrm{Z}$ and the views of Generation $\mathrm{Z}$ to school administrators.

The purpose of this study to examine school administrators and the students of Generation Z's perspectives for each other. This study sought answers to the sub-questions below:

Research question 1: First research and the related sub questions examine the views of school administrators from the following perspectives:

- Which factors affect school administrators' interactions with students?

- To what extent do school administrators experience generation gap with students from Generation Z?

- What sorts of relationships do school administrators and Gen Z establish?

- What sorts of problems and obstacles do school administrators encounter in their interaction with students of Generation Z?

Research question 2: Second research and the related sub questions examine the views of Generation $\mathrm{Z}$ students from the following perspectives:

- What are the students (students of Generation Z) perceptions of school administrators?

- What are the expectations of Generation $\mathrm{Z}$ students?

- What sorts of problems and obstacles do students of Generation $\mathrm{Z}$ encounter?

\section{Method}

In this section, the most appropriate method is chosen for the purpose and scope of the research. The preferred pattern of the model is described by the researcher in a literature-based manner.

\subsection{Research Design}

This research was based on the phenomenological method of qualitative research. The phenomenological method aims to describe, understand and interpret the meanings of experiences of human life. It focuses on research questions such as what it is like to experience a particular situation (Bloor and Wood, 2006). The phenomenological design "that questions the perceptions and meanings developed by individuals after their experiences" (Ersoy, 2016, p. 104) was 
used in revealing the experience and the individual's perceptions of these experiences from their own perspectives and in analyzing the data (Lester, 1999). Research group consists of 15 school administrators, who serve in private and public elementary / high schools in Kadikoy district in Istanbul, Turkey. 20 students, members of Generation Z born after year 2000, also constitute the study group.

\subsection{Data Collection Procedure}

Face to face interviews were conducted with the participants. Reflective listening technique is used during interviews conducted in a semi-structured interview format. In this technique, the researcher identifies and empathizes with the participants, and focuses on the participant's words, gestures, and tone (Jentz and Murphy 2005).

Authors followed all the ethical and legal procedures during the interviews. Participants were sent a letter inviting their voluntary participation, informing them of participation requirements and safeguards, and asking that they certify their informed consent. To interview participants, researchers contacted them through emails and they also contacted the students through their teachers. Participants were reassured that their identities and all identifying information would remain confidential. No real names were listed on any documents or data related to this research.

\subsection{Data Analysis}

Content analysis is employed to analyze the data gathered during the research process. The aim of content analysis is to organize the data related to each other, and collect them together and comment on them in a way to enable the reader to comprehend easily (Yildirim and Simsek, 2006). The data was analyzed using NVIVO 10. In the research, a code was given to each participant. For instance, the administrator of the school X in Kadikoy was registered with the code SA1 (school administrator 1), and the others followed as SA2, SA3 ...... SA15 while student participants were given the codes of S1, S2, S3...S20.

All the interviews were recorded and transcribed word-for-word. Analysis of the interviews was divided into five phases suggested by Marshall and Rossman (1999), these include: "organizing the data, identifying themes, patterns and categories, testing the emergence hypothesis against the data, searching for alternative explanations of the data and writing the report." Authors also used some of the quotations to reveal the lived experiences of the administrators and students.

\section{Findings and Interpretation}

The findings gathered from two different groups, the former school administrators and the latter members of Generation Z.

\subsection{The Findings Related to School Administrators (Research Question 1)}

The data was categorized under two main themes: The first theme was based on 'Generation $\mathrm{Z}$ from the perspectives of school administrators'. The subthemes consist of 'the factors which affect school administrators', 'the generation gap in education', 'the relationship between school administrators and students' and 'problems and restrictions'.

\subsubsection{Theme 1. The Factors Which Affect School Administrator}

The factors which affect the school administrators can be categorized under three headings: 'parent', 'technology' and 'environment'.

Tablo 1. The factors which affect school administrator

\begin{tabular}{llc}
\hline The factors which affect school administrator & (person) & (attribution) \\
& $\mathrm{n}$ & $\mathrm{f}$ \\
\hline 1. Parent & 15 & 22 \\
\hline 2. Technology & 9 & 15 \\
\hline 3. Environment & 5 & 6
\end{tabular}

The new profile of students named as Generation $\mathrm{Z}$ influenced the lives of school administrators in many ways. That why this theme is entitled as the "factors which influence the many lives of school administrators". Being a school administrator is a high stakes position that requires a lot of commitment and compensation. Changing conditions in educational contexts makes this role more challenging. This study shows that factors related with "parents, technology and environment" serve as road blocks that schools administrators need to overcome.

Factor 1. Parent: The first factor affects the school administrators' lives is the changing profile of parents and their over-protective and demanding attitude. Some of the people involved in the research group are mentioned below: 
"The profile of parents has changed over time. They expect us to make compromises for their children. This generation prefers to strengthen themselves and stand against us with their parent's support" (SA11).

"I observe how powerful a student can become with their parents' support even if he has made a mistake. This power enables him to tyrannize over the teachers and the school" (SA9).

"The parents control and influence on today's children is insufficient." If the family does not cooperate with school administrators and cannot reach any sort of consensus, then the desired school performance cannot be achieved" ( SA15).

"Sometimes, it can be more difficult to persuade a parent than persuading a child." If the both sides are on the same page and supervise the children together, the problem will be over" Because the children are affected by both by their family and surroundings". It is essential to make children believe that the school's applications are true" (SA10).

Factor 2. Technology: The second factor of the research question 1 focuses on the adverse effects of the use of technology at schools from the perspective of school administrators. Some of the people involved in the research group are mentioned below:

"The current generation doesn't use technology consciously enough. For now, we observe some adverse effects like becoming unsociable and undisciplined. There is no auto control and there is no control mechanism." Unfortunately, children are left loose about the use of technology" (SA10).

"There is another life and Generation $Z$ experiences it to the hilt. In particular, social media has a powerful influence on young people. When used maliciously, it is detrimental to both children and education system, but if used properly, it is quite useful" (SA14).

"Technology has begun to be used in the schools, however; we do not possess the facility and the maturity to utilize it effectively. A child comes to the school with his Ipod and leads teachers to have hard times in using the smart boards and the internet use by breaking the passwords. Interesting, yet nowadays, the greatest problem of us is the use of smart phones at school" (SA3).

Factor 3. Environment: The third factor is concerned with the importance of outside relations and lives of the students and its negative impact on the school administrators' performance in dealing with students. Some of the people involved in the research group are mentioned below:

"The personal affairs out of school are quite important. This generation brings their personal affairs to the schools and perceives the school as their home. The children of fragmented families that have been involved in crime can be rather troublesome for school administrators. In past, the fragmented families are few in numbers, but today, it is quite a lot" (SA14).

"Popular culture has a negative influence on the teenagers" (SA11)

3.1.2 Theme 2. The Generation Gap in Education

A generation gap or generational gap, is a difference of opinions between onegeneration and another regarding beliefs, politics, or values. In today's usage, "generation gap" often refers to a perceived gap between younger people and their parents or grandparents. The codes related to the generation gap in education are as follows: 'the old generation', 'the new generation', 'time, change and the generations'.

Tablo 2. The generation gap in education

\begin{tabular}{lcl}
\hline The generation gap in education & (person) & (attribution) \\
& $\mathrm{n}$ & $\mathrm{f}$ \\
\hline 1. Old generation & 7 & 11 \\
\hline 2. New generation & 12 & 20 \\
\hline 3. Time, change and the generations & 6 & 7 \\
\hline
\end{tabular}

Some of the opinions related to the codes are given below:

Factor 1. The old generation: Schools administrators views of the students of generation $\mathrm{Z}$ is given under the title of the old generation. Following excerpts reveal their ideas under this sub theme.

"When compared with the old times, the use of corporal punishment used to be common at schools, and there were other heavy discipline penalties. There used to be teachers that could go out to the garden and smoke. However, today, this is forbidden, there are really many differences between the past and now. To apprehend this process, it is vital to listen the three generations' students and teachers" (SA5). 
"In the past, fear was very common in student, but now it is not the same. The elder administrators have more difficulty in getting accustomed to the situation when compared with the younger ones. According to them, the current generation is spoiled” (SA10).

"In our age, our teachers used to mean a lot to us. They would even come first before our parents. They were the idols that we used to take as role-models" (SA3).

"Parents would say 'Don't spare the rod!. As the older generation, we are not under the impact of the digital age. We prefer the natural relationship forms; face to face or eye to eye interactions" (SA4).

Factor 2. New generation: As for the new generation the following quotations are shared:

"What I recognize in the new generation is that they are excessively individual, and they come to school by learning the knowledge in advance because they can access the information easily. Since they know everything; a teacher is no longer the person who knows everything and acts correctly. And consequently, they approach to the teachers with critical eye" (SA2).

"I take their critical attitude naturally, but not the exaggerated ones. Our new generation can sometimes criticize in vain without any point at all” (SA3).

"Generation $Z$ is bothered easily by scolding, punishment, oppression, threat, information letter given to the family and supervision. The imperative sentences frighten them and led them to skip the school... The youth of Generation $Z$ behaves with extreme individualism, they say: 'I can do it myself, I do not need anyone, and I am free.... But life is hard, and therefore, these students should be convinced, guided to the right path and supervised" (SA4).

Factor 3. Time, change, the generations: Following quotations for the factor 3. time, change, the generations are shared by the school administrators.

"The rapid change and the need of development can create loopholes. The rules may not keep up with the requirements of the age. But I believe, they fill in the gaps gradually” (SA2).

"We are confronted with a difficult generation compared to our age. We also need to adapt ourselves to the changes" (SA10).

"People need to modernize themselves according to the demands of the changing age. We can not come to anywhere if we try to apply our old rules in the new age. We need to keep up with the times, and when we raise our children according to future developments, and then everything is alright. It is not plausible to stick to the old rules. We need to work in an open minded way by keeping the prospective future in mind" (EY13).

3.1.3 Theme 3. Relationship Between School Administrators and The Generation Z

This part of the study is concerned with the 'relationship between school administrators and generation $\mathrm{Z}$ students', which involves the viewpoints regarding 'school administrators' perception of Generation Z' and 'school administrators' attitude towards generation $\mathrm{Z}$ students'.

Table 3. Relationship between school administrators and students

\begin{tabular}{llll}
\hline $\begin{array}{l}\text { Relationship between school administrators and } \\
\text { students }\end{array}$ & $\begin{array}{c}\text { (person) } \\
\mathrm{n}\end{array}$ & (attribution) \\
\hline $\begin{array}{l}\text { 1. School administrators' perception of } \\
\text { generation Z }\end{array}$ & 13 & 24 \\
\hline $\begin{array}{l}\text { 2. School administrators' attitude toward } \\
\text { generation Z students }\end{array}$ & 17 & 28 \\
\hline
\end{tabular}

Factor 1. School administrators' perception of generation Z: The sub theme 2 firstly dwells on the "school administrators' perception of generation Z" to describe the challenges the school administrators face due to new characteristics of the generation $\mathrm{Z}$ students. The quotations below reveal that difficulties are instructional for the school administrators as it improves their insights.

"They belong to different generation and of course, they push the limits of school administrators because they are always online, it's strenuous to control them while they are surfing on the net. You don't have an idea of what they have been doing or what they have been thinking of. In the past, everything could be done with a piece of paper. If a child was in love, he used to write it in his diary, but now he writes and declares his love via WhatsApp, twitter or Facebook networks. For school administrators, it is hard to follow. This generation overstrains all school administrators. Now, a child can effortlessly contact with a person who lives anywhere in the world. Now, everything becomes universal. To restrict a child living freely can lead to negative consequences. A child reacts this negatively" (SA5). 
"I guess this generation is too demanding for school administrators. The reason is generation gap. If we overlook the characteristics of this generation, it is highly likely that the teachers and school administrators belonging to the Generation $X$ and $Y$, have difficulties in dealing with them" (SA6).

"This generation forces the limits of school administrators because they want to stand up for their rights and express their opinions freely. Of course, today, they are raised in such a democratic atmosphere, but sometimes they confuse the borderline between respect and freedom" (SA2).

"This generation is problematic compared to our generation. Actually, this is what we want. A child should not be raised up with predetermined rules. We should allow child to develop himself. It is essential to support them not only on educational terms, but also in terms of social, artistic and cultural dimensions. Therefore, at this phase of their life, I think that it is necessary to support their enthusiasm for research and self-improving moves" (SA1).

"They have a strong sense of criticism. As they criticize, we refresh ourselves. We learn a lot from them, such as the perspective of the youth and the generation gap" (SA13).

Factor 2. School administrators' attitude toward generation Z: The sub theme 2 secondly focuses on "school administrators' attitude toward generation Z". It summarizes the suggested attitudes the school administrators should take when dealing with generation $\mathrm{Z}$ students. The school administrators explain the key terms that enable them to win generation $\mathrm{Z}$ students' approval and affection through several quotations below:

"Planned, well planned advices and warnings, and advices and warnings given on the right time have a big impact on the students' improvement. What I mean by warning is coaching, a sort of mentorship. Not a constant intervention" (SA6).

"When you give timely and necessary reactions, then the students can accept it without hesitance. The experience I have had so far shows that the teachers should not call the students, "friends". When you act your role as a teacher and a school administrator well, it becomes easier to establish authority. Approaching them friendly, the formality between student-teacher and student and school administrator is destroyed" (SA14).

"The student should come and leave school happily. When this is realized, the education and training can proceed successfully. When the happy atmosphere is created, success follows. But if people exceed the rules, and that make the others unhappy, it is a big issue. The rules should be applied equally for all" (SA10).

"When a student understands that you love him, his attitude changes towards you. However, when he does not believe that you love him, then, whatever you do, you cannot be influential on this student. What goes around comes around" (SA13).

\subsubsection{Theme 4. Problems and Restrictions}

The theme codes for "problems and restrictions" are 'bureaucratic obstacles' and 'deficiencies in the education system'. The opinions of the participants related to the codes are summarized below:

Table 4. Problems and restrictions

\begin{tabular}{lcc}
\hline Problems and restrictions & $\begin{array}{c}\text { (person) } \\
\mathrm{n}\end{array}$ & $\begin{array}{c}\text { (attribution) } \\
\mathrm{f}\end{array}$ \\
\hline 1. Bureaucratic obstacles & 5 & 5 \\
\hline 2. Deficiencies in the education system & 11 & 18
\end{tabular}

Factor 1. Bureaucratic obstacles: The sub theme 3 explains the school administrator's problems and restrictions. The first one to start with is bureaucratic obstacles school administrators' endure due to role ambiguity arises from vague and ill-defined job description.

"The meaning of vice principal in the Ministry of Education is essentially not more than an office clerk. It is not related to management. Through achieving value-added goals, school administrators are expected to make the school more prestigious and different from the other schools, and play leadership role to encourage his followers, who are teachers, students, and staff, to make them stay focused on the target. However, in national education, this is almost impossible. There is abundance of unnecessary works to do, which is time and energy consuming. Moreover, according to the ministry of education, everything is defined according to law. There are a lot of regulations and principles. You cannot take initiative. It is not possible to act flexibly" (SA6). 
"As a vice principal, I can say that according to school regulations, a vice principal simply works like an officer. In fact, dealing with the students must be our first duty. However, we cannot spare time for them due to running the chores in the office, which in the end reduces the quality" (SA8).

Factor 2. Deficiencies in the education system: The second problem school administrators experience is deficiencies in the education system. This part presents school administrators viewpoints on the issue with a special focus on the deficiencies like adaptation problem to the changing conjecture and formation of democratic school regulations.

"I believe that the regulations should not be determined according to the given provisions of headquarter. In essence, I don't believe that it is right to determine in what situations students should get reprimand, suspension, and reward by headquarter. I believe the school regulations should be created through workshops, surveys or different kind of activities that student- teacher works in collaboration, and should be also be changed over time.

The conjuncture is changing and if the rules are determined together with everybody's involvement, it will get people's approval much more easily. Thus, it will erase the idea that the regulations are imposed upon us... Yet the national education system is getting worse because the process that is devoid of plans, rationality and science can not be successful. When looked from top to toe, the national education appears not well-organized. We can clearly observe that even if each step is taken with well-intentions, it brings about wrong consequences. The major reason is that we don't think, search, analyze and plan. My own solution is that there must be a quick paradigm change concerning the national education system not just on paper, but in practice. It is essential to raise teachers according to the changed paradigm. This can occur at least within 20-25 years in Turkey. Not today. The steps that are taken give just temporary solutions to save the day, there is no long-term academic calendar” (SA6).

"The generations are changing over time, but the teacher's mentality does not change. The teachers should adapt themselves to the changing conditions, and the rules should also be adjusted to the new discipline system. In past, what we understand from the discipline is oppression, fear and penalty, but now I take it differently. The rules, therefore, should be decided upon an agreement and consent of the all shareholders of the system" (SA6).

"It's natural that the new generations are different from others. The education system has been preserved the same, though. It is not possible to manage the time and the process” (SA12).

"There is disconnection between primary education and secondary education. I think there is caused by the past unsettled decisions taken” (SA11).

"Generation $Z$ is challenging to school administrators. Therefore, there must be a new system. I mean the requirements of the system ties administrators' hands. The ambiguities in the system lead our teachers to feel tired and exhausted" (SA3).

\subsection{The Findings Related to Generation Z (Research Question 2)}

The main themes obtained as a result of research question are as in the following: 'school administrators from the perspective of generation Z', 'the attitude of generation $Z$ students towards school administrators', 'generation $Z$ students' expectations from administrators' and 'problems and restrictions'.

\subsubsection{Theme 1. The Attitude of Generation Z Students Towards School Administrators}

The main codes of "generation Z's perspective of school administrators" are determined as "the feelings and attitude of generation Z students towards school administrators", "heeding school administrators and role modeling". The subtopics are categorized into two: 'the ones who take SA role model' (8/20) and 'the ones who do not take SA role model' (6/20). Some of the participants' comments are given below:

Table 5. The attitude of gen $\mathrm{Z}$ students towards school administartors

\begin{tabular}{lll}
\hline $\begin{array}{l}\text { The attitude of gen } \mathrm{Z} \text { students towards school } \\
\text { administartors }\end{array}$ & $\begin{array}{c}\text { (person) } \\
\mathrm{n}\end{array}$ & $\begin{array}{c}\text { (attribution) } \\
\mathrm{f}\end{array}$ \\
\hline $\begin{array}{l}\text { 1. The feelings and attitude of students of gen } \mathrm{Z} \\
\text { students towards school administrators }\end{array}$ & 20 & 44 \\
\hline $\begin{array}{l}\text { 2. Heeding school administrators and role } \\
\text { modelling }\end{array}$ & 18 & 8 \\
\hline $\begin{array}{l}\text { 2.1. The ones who take SA role model (8/20) } \\
\text { 2.2. The ones who do not take SA role model } \\
(6 / 20)\end{array}$ & 6 & 6 \\
\hline
\end{tabular}


Factor 1. The feelings and attitude of students of generation $\mathrm{Z}$ towards school administrators: The first sub theme under the research question 2 firstly discusses the viewpoints of the generation $\mathrm{Z}$ students towards school administrators. Following words reveal the views of students:

"I suppose that school administration is one of the most difficult occupations in the world. Actually, I know that it is too demanding to deal with us” (S10).

"Unfortunately, many school administrators are brought up with the perspective that 'The student has to do what I tell him to do. 'However, some new age teachers seem to have been changing this perception” (S19).

"I do not feel that they consider me as an individual and regard my thoughts" (S11).

"I regard them just as the workers who run, regulate, and check our start and leave times" (S18).

Factor 2. Heeding school administrators and role modeling: Another point that research question 2 examines is generation Z students' two different approaches concerning the issue of role-modeling. Whether school administrators serve role models or not is the central question which the generation $\mathrm{Z}$ students discuss with the following point of views:

Factor 2.1. The ones who take SA role model:

"The methods they use were effective in our lives. I mean they can be role models" (S16).

"From primary school to college, School administrators are always role models for us. However, if you think that the administrator got the position with his own efforts” (S5).

Factor 2.2. The ones who don't take a role model:

"School administrators' remarks must be consistent with their actions. I don't take them as a model because of their inconsistent behaviors” (S6).

"I do not remember an educator who I would be able to consider as a role model” (S15).

"To me, administrator is someone ordinary. I do not identify myself with them" (S18).

"The administrators" being overly authoritarian has caused me to develop prejudices. If I were an administrator, I thought I wouldn't behave like them" (S4).

\subsubsection{Theme 2. Generation Z Students' Administrative Expectations}

The subtopics are a 'generation Z students' administrative expectations' are 'how must a school administrator be?' and 'expectations from school administrators', The participants' opinions are summarized below:

Table 6. Generation Z students' administrative expectations

\begin{tabular}{lll}
\hline Gen Z students' administrative expectations & (person) & (attribution) \\
\hline 1. How must a school administrator be? & $\mathrm{n}$ & $\mathrm{f}$ \\
\hline 2. Expectations from school administrators & 15 & 32 \\
\hline
\end{tabular}

Factor 1. How should a school administrator be?: The subtopic of the sub theme 2 focuses on the generation $\mathrm{Z}$ students' various opinions with regard to characteristics and qualities they expect to see in school administrators and the answers given below illustrate their ideal portrayal of school administrators. From the perspective of generation $\mathrm{Z}$, two issues come to forefront: School administrators' personality traits and their method of establishing disciplined school environment. Voices of school administrators are as follows:

"If he acts according to the rules, students become disciplined. Yet, he loses his sense of humor. If he can balance to apply the rules well, he may be a nice character" (S18).

"According to me, the school administrator must be disciplined, apply the rules, and when the rules are not obeyed, he will accordingly give the deserved penalty. He must be fair. The school administrator should possess the features like identifying himself with the students, listening their opinions, giving advices to enlighten them, and in case undisciplined actions occur, he should find out the reasons for these actions rather than immediate punishment” (S3).

"School administrators must keep distance between student and himself. He should be sincere but also keep his seriousness" (S16).

Factor 2. Expectations from school administrators 
"The best school administrator is the one who can understand and love students. I believe that administrators must be young enough to understand students. Elder school administrators are generally bad-tempered and inconsiderate. Moreover, principals shouldn't use humiliating remarks towards students” (S14).

"Administrators should apply to the rules when there is a second time violation of the rules" (S20).

\subsubsection{Theme 3. Problems and Restrictions}

The theme of 'Problems and restrictions' has two subtopics: 'Democratic restrictions' and 'Communication problems'. Some of the participants' opinions are stated below:

Table 7. Problems and restrictions

\begin{tabular}{lcc}
\hline Problems and restrictions & (person) & (attribution) \\
& $\mathrm{n}$ & $\mathrm{f}$ \\
\hline 1. Democratic restrictions & 12 & 34 \\
\hline 2. Communication problems & 7 & 11
\end{tabular}

Factor 1. Democratic restrictions: The sub theme four focuses on the problematic aspects affecting generation $\mathrm{Z}$ students' school lives. The participants acknowledge that the biggest problem is creation of democratic school environment, which is caused by the school administrators' traditional outlook on discipline, rules, and penalty. As generation $\mathrm{Z}$ students express their critical insights, they also offer possible solutions below:

"I think there must be a democratic environment in a school. The school has a fake democracy. Instead, there is an absolute dictatorship"(S6).

"Due to my personality, I easily violate the school rules because there is pressure. The pressure incites us to break with the rules. When they decide the rules, it had better to take students' opinions. It is better to find the middle ground for both sides"(S3).

"School administrators dictate both to teachers and students" (S12).

Factor 2. Communication problems: Another problem influence generation $\mathrm{Z}$ students is communication handicap between generation $Z$ students and the school administrators. The students' discomfort and hesitance due to school administrators' restrictive and oppressive attitude is exemplified with the following remarks of the students:

"An administrator who insults me in front of the crowd causes me to lose my enthusiasm for school. If my proud were broken, I would behave wrongly” (S15).

"My obedience to the rules is related with the administrator's attitude. If he forces me, I would definitely not obey. But if he says, you had better not do it and approach me in a kind and sensible way, and then I would obey the rules" (S3).

"Sometimes they want us to act like robots. I think it is impossible for everybody to obey the same rules because everybody individual is different and they do not have the same personality” (S10).

\section{Conclusion and Discussion}

Globalization and technological change means that tomorrow's workforce must be equipped with new skills and should be ready to learn throughout life, especially with new ways, such as; solving real problems, using multiple disciplines and accessing to the best content (Cisco 2009). However, researches show that the countries fail to meet the needs of new generations due to the continuation of the classical education system and lack of content.

Every generation has different characteristics of education and learning strategies. Studies show that learning styles can be categorized according to the students' generations (Pacis et al. 2012). Then, this brought us to the conclusion that the new generation learns differently from the other generations, but as this research also examines, school administrators, who still keeps traditional approach cannot respond to the different student profiles effectively due to their traditional outlook on education. Therefore, Educators should accept multiplicity and individuality in learning styles and use different learning techniques to satisfy today's students' needs and expectations.

In a world where politics, religion, education, art, love, sorrow, terror and violence are presented as an entertainment, all the interlocutors, particularly the educators are expected to take serious steps to prevent youth from alienation to the society and the world he lives in. The youth in Turkey should be educated as individuals with unique intellectual capacities to create antidote against the standardizing and hegemonic impacts of popular consumption culture. If urgent measures are not taken, today's youth, being subjected to the imaginary values offered by the social media and network tools, will be more and more selfish, anxious, hateful, angry and voluptuous in the end (Sahin 2005). 
The whole world is turning into an "open-air madhouse" gradually but with firm steps (Twenge 2009). In this research, it is also shown that the participants' definition of the new generation is in line with Twenge's idea that the youth is getting alone and selfish over time. As Şahin stated above, in order to prevent the youth to waste their strong potentials, particularly the educators are expected to take serious steps.

The invention of the internet brought out a new generation called "the Net Generation". Interaction and friendship established through the net and social media networks become more enjoyable for teenagers. Young people consider being online as unexceptionable platform to socialize, meet and have fun. It is known that internet has a growing potential since past because it becomes popular among people even the days when it is primitive, slow, limited or insecure. People keep using it (Topscott 1999). From the past years to the present day, the internet, one way or another, influence the dynamics of our life, in educational dimension, its effect is profound because it produces Generation $\mathrm{Z}$ students with modern educational outlook.

This new generation of students has different expectations from life. They have distinct social characteristics and different ways of thinking and learning. They prefer to reach the information quickly by using communication technologies, multitasking and having no interest in traditional lectures comprised of passive listening and note taking. Instead, they prefer active learning process, and demand a change in pedagogical models of education that relies on teacher-centered approach rather than student-centered approach (Jones and Shao 2011).

Generation $\mathrm{Z}$ students expect the technology integrated learning and teaching program, but the educators fail to meet this expectation. If the technology is set and integrated appropriately, it will really foster teaching and learning process in education. Technology also helps to increase the productivity. That is, to manage the process of education becomes easier thanks to online participation, mass notification systems and video streaming applications. Technology also facilitates equality in education. The students all over the world are able to reach the resources, information, experts and contact with each other regardless of distance and space (Cisco 2009). Although the technology has numberless facilitating outcomes for education, nevertheless as Simsek and his friends' research on technology (2009) found out, quite a few studies have been made in the field of educational technologies, and they are focused only on several specific issues. The researches, which are common at the beginning of the 2000's, are generally clustered around the traditional topics like the use of instructional technologies and computer-aided teaching. It seems that Turkey has still been keeping its traditional stance concerning the science and technology even on the verge of the new millennium. As far as the data collection instruments, sampling methods, statistical techniques, it can be concluded that there is only a few innovative researches carried out so far.

The results of our study indicate similarity with Simsek and his friends' conclusions. Our schools' technological infrastructure is still poor, and school administrators still cannot decide to what extent they will let the students to use technological devices at school. TED (2016) researches found out that when the reports of Eurostat, ITU, Index, Web index concerning Turkey's evolution into the Information Society are examined, as a EU member, Turkey stands in the last row among other EU countries. Despite the fact that there has been a growing awareness of information technologies and allocation of budget, it is still a big issue to reap effective outcomes and create added value.

The educational system in existence is a monopolistic system designed for industrial era. Even if this system seems quite good for mass production, it does not meet the requirements of digital generation seeking multiplicity in learning Instead of implementation of single dominant education system applicable to each student; schools should take individual needs into consideration and customize the education accordingly (Topscoot 2009).

The administrators do not attain their goals when changes are made by dribs and drabs in educational system just to keep up with the times. As the participants mentioned in the research, our educational system needs a development in paradigms. Gelen and Beyazit (2007) states that program development is not assumed as a normal process in Turkey. Therefore, Turkish educational system does not have a settled education culture and the adopted programs do not lead the students to attain specific goals. Program development is not about changing the program on the desk and removing some topics and replacing them with new ones. The program development is practical and dynamic process, in which all conditions related to the educational process, individuals, and tools, written sources are continually developed.

In TED (2016) National Curriculum Program explanations, for the purpose of school administrators' recovering from the current situation, in which the success of the system is heavily, relies on the administrator's success, school administrators should be held accountable for only performing administrative tasks. To ensure qualified education, proactive education leaders should be valued, and their roles should be increased for a successful school. In this regard, administrators should be education leaders who can adopt vision and values that required by professional process, use his knowledge and different approaches, and have strong personal characteristics that endow him with capability to maintain bilateral and social relations in all processes. 
In addition, administrators should pay attention to the classroom activities to be active, collaborative, and social and student-centered because otherwise students get easily bored and distracted from the learning process. It is essential note that these students engage with digital and technological devices and communication ways (Berk 2009). They are quite reserved and may not be accustomed to dealing with conflicts as other generations do. Therefore, special training programs should be organized to develop team building, negotiation and conflict-solving skills (Saleh 2009).

The youth, who is an important dynamic in the progression of the society, should be raised up physically and mentally healthy so that they can secure the future. To ensure this, it is essential to solve out the problems and depression of the youth. Beyond everything else, it is vital to implement educational policies that make the youth to discover their potential to cope with their own problems, to recognize their ability as individual with high self-respect and self-sufficiency and enable them to discover their creativity (Sahin 2005). In our study, it is pointed out that Generation $\mathrm{Z}$ students demand an education system that pays attention to individual differences. In recent years, learner centeredness and cooperation is emphasized in Turkish Education System. However, the competitive testing system makes it hard to maintain student-centered and cooperative approach at schools. It is also found out that the testing system in Turkey is challenging for Generation Z students. This generation is not only feel isolated due to technology but also they also struggle with the stressful testing system. For this reason, Generation $\mathrm{Z}$ wishes to choose where, when and what kind of education they will get. Students imagine classrooms surrounded by technological devices and wish teachers to utilize from videos and video games in lessons. They would rather peer teaching rather than learning from a lecturer (Beyers, 2009). This suggests that, first and foremost, the educators should be trained about the defining characteristics of Generation $\mathrm{Z}$ and learn to incorporate technology to the instructional program and provide students with a cooperative learning atmosphere, where peer teaching and scaffolding process is maintained rather than lecture, under the control of the teacher and the employed via the use of technological devices.

Celen, Celik and Seferoglu (2011) who state that Turkey is not successful in increasing its score to a higher level, and claims quantitative changes must be followed by qualitative changes in order to make significant changes in PISA scores. Considering the socio-economic structure and current situation in Turkey, it has been known that opportunities are limited. These projects are crucial in that they provide permanent learning by implementing the use of multimedia to appeal to multiple senses.

Outdated and traditional educational approaches cause the new generation to become a complicated mass of population. Even in 21st century, the countries still lack effective educational approaches, classroom activities and academic support. Improving the students' level of education is not only the student's responsibility as an individual, but also the responsibility of the whole society and the institutions. For better generation, institutional capacity needs to be strengthened, and this requires institution to create an educational program that seeks a common target in relation to academic achievement of student (Issue Brief 2012).

This study revealed that the perspectives of school administrators and Generation Z student toward each other. In this study, expectations, and responses and critical insights are examined from the lenses of school administrators and students in a way to provide recommendations that could be remedy for the concerns of the school administrators and Generation $\mathrm{Z}$ students not only in theory but also in practice. The results of the study can be grouped under two main headings: the results of the interviews with Generation $Z$ students and the results of the interviews with school administrators. Since Generation $\mathrm{Z}$ students have an access to limitless freedom and knowledge via digital world, they feel restricted when strict rules set by the school administrators. The majority of Generation $\mathrm{Z}$ students hold the belief that each individual is unique, and therefore, they demand administrators to pay attention to individual differences, respect to their personal rights and private space. In addition, the majority of the participants also expect school administrators to get their opinions about the rules, be fair in its implementation, and abstain from giving punishment in their first mistake.

Generation $\mathrm{Z}$ students also consider that school administrators cannot abandon traditional pedagogical strategies and testing system and fail to meet the needs of new generation by keeping abreast of technological advancement, and therefore; they are unable to incorporate the technology into the instructional program as effective as the students expect. The students do not perceive the administrators as role model anymore, but they still value and respect if administrators are fair, and can hold balance between sincerity and seriousness. Generation $\mathrm{Z}$ students expect administrators to be young so that they can understand, identify and communicate with them appropriately.

From school administrator's perspective, the generation gap is a big issue to be dealt with, but the study also reveals that emerging new generation with new demands, the adaptation problem to the modern instructional technologies and computer-aided teaching system, the role ambiguity, parent's approach and outside relations influence quality and school management adversely. According to them, they are challenged by weak infrastructure at schools and ambiguous approach about the use of technology in class, which eventually give rise to an uncontrolled and undisciplined lost 
generation. Another important challenge school administrator's face is teachers' demotivation. Also, the assistant principals, who are overburdened with work and used as an office clerk, are unable to exert school management which decreases the quality of education. The other noteworthy result is that strict rules and fear hegemony employed in the education system of generation $\mathrm{X}$ and $\mathrm{Y}$ have lost its validity in today's education system. Education administrators should be informed about the generations from the basis of sociology and given the opportunity to analyze generations. Related workshops can be tailored to meet the demands of the society. In this way schools can keep up with change and development. As school administrators and teachers serve as the facilitators in this process, they should be given support for their professional development. This support could be in the form of better working conditions as well as creating platforms in which they could learn from each other.

\section{References}

Adiguzel, O., Batur, Z. H., \& Eksili, N. (2014). Generation's changing side and the newly arisen work style after y-generation: mobile collars. Journal of Suleyman Demirel University Institute of Social Sciences, 19, 165-182.

Berk, R. A. (2009). Teaching strategies for the net generation. Transformative Dialogues: Teaching \& Learning Journal, 3, 1-24.

Beyers, R. N. (2009). A five dimensional model for educating the net generation. Educational Technology \& Society 12, 218-227.

Bloor, M., \& Wood, F. (2006). Keywords in qualitative methods. London: SAGE Publications Ltd. https://doi.org/10.4135/9781849209403

Celen, F. K.., Celik, A., \& Seferoglu, S. (2011). Turkish education system and PISA results. Conference of Academic Information Technology, 2-4, 765-773.

Cetin-Aydin, G., \& Basol, O. (2014). X and Y generation: is there a change in the meaning of work? Electronic Journal of Vocational Colleges, 4, 1-15.

Cisco, (2011). Transforming education, transforming lives: a path toward next generation teaching and learning. Connected Insight Series. Retrieved from http://www.cisco.com/c/dam/en_us/solutions/industries/docs/education/transforming_edu_wp.pdf. at12.08.2016

Demirkaya, H., Akdemir, A., Karaman, E., \& Atan, O. (2015). Research on expectations of generations for management policies. Journal of Business Research Turk, 7, 186-204. https://doi.org/10.20491/isader.2015115758

Ersoy, A. F. (2016). Dördüncü sınıf öğrencilerinin hoşgörü algısı ve deneyimleri: Bir fenomenolojik araştırma [The tolerance perception and experiences of fourth grade students: A phenomenological study]. Mersin Üniversitesi Eğitim Fakültesi Dergisi, 12(1), 454-473. https://doi.org/10.17860/efd.31740

Gelen, I., \& Beyazit, N. (2007). Comparing perceptions of the new primary school curriculum with the former curriculum. Educational Administration: Theory and Practice, 51, 457-476.

Gurbuz, S. (2015). Generational differences: a myth or reality? The Journal of Human and Work, 2, 39-57.

Guthrie, L. (2009). The next generation of workers. The Ken Blanchard Companies, 3, 10-14.

Issue Brief. (2012). Supporting first-generation college students through classroom-based practices. Institute for Higher Education Policy, 1-30, Washington DC.

Jentz, B. C., \& Murphy, J. T. (2005). Embracing confusion: what leaders do when they don't know what to do. Phi Delta Kappan, 86(5) pp. 358-366 https://doi.org/10.1177/003172170508600506

Jones, C., \& Shao, B. (2011). The net generation and digital natives. Implications for higher education, a literature review commissioned by the Higher Education Academy, 1-53.

Lester, S. (1999). An introduction to phenomenological research. Taunton: Stan Lester Development. Retrieved from https://www.rgs.org/NR/rdonlyres/F50603E0-41AF-4B15-9C84-

BA7E4DE8CB4F/0/Seaweedphenomenologyresearch.pdf

McQueen, M. (2011). Ready of not... here come Generation Z. A look at the generation about to hit high schools, workplaces and society-at-large. Retrieved from http://textlab.io/doc/514489/ready-or-not--here-come-gen-z

Oral, G. A. (2013). Generations in working life and conflicts. MA Diss., Bahcesehir University, Istanbul.

Pacis, D., Sytsma, C., Weegar, M. A., Keough, P., Wheeler, D., \& Bustillos, T. (2012). Educational achievement and satisfaction through generations. International Journal of Business and Social Science, 21, 57-62.

Quinn, S. (2010). Generational challenges in the workplace. Bissett School of Business and Ventus Publishing. 
Sahin, M. C. (2005). Social identity of the youth in Turkey and popular consumption culture. Gazi University Journal of Gazi Educational Faculty, 25, 157-181.

Saleh, K. L. (2009). Managing to manage across generations at work. The Psychology Foundation of Canada, In Partnership with Desjardins Financial Security.

Schofield, C. P., \& Honoré, S. (2010). Generation y and learning. The Ashridge Journal, 26-32.

Simsek, A., Ozdamar, N., Uysal, O., Kobak, K., Berk, C., K1lıcer, T., \& Cigdem, H. (2009). Current trends in educational technology research in Turkey in the new millennium. Educational Sciences: Theory \& Practice, 9 , 961-966.

Skene, J., Cluett, L., \& Hogan, J. (2007). Engaging gen y students at university: what web tools do they have, how do they use them and what do they want?. The University of Western Australia. http://fyhe.com.au/past_papers/papers07/final_papers/pdfs/2b.pdf

Tapscott, D. (1999). Educating the net generation. Educational Leadership, 56, 6-11.

Tapscott, D. (2009). Grown up digital. McGraw Hill, New York.

TDK. (2016). Large Turkish Dictionary. Retrieved from http://tdkterim.gov.tr/bts

TED. (2015). National Education Programme. 2015-2022 April 11. https://tedmem.org/yayin/ulusal-egitim-programi

Tolbize, A. (2008). Generational differences in the workplace, Research and Training Center on Community Living, University of Minnesota.

Twenge, J. M. (2009). Generation me. İstanbul: Kaknus Publishing.

Ulker, H. (2013). What is Y generatin? (Y kusagi da neyin nesi?". Retrieved at 03.04.2016 from http://acikarsiv.atilim.edu.tr/browse/791/Y\%20kusagi.pdf.

Yucebalkan, B., \& Aksu, B. (2013). A research about the interoperability of potential labor generation y with transformational leaders. Journal of Organization and Management Sciences, 5, 16-32.

Zehir-Topkaya, E. (2006). Qualitative research methods in social sciences. Journal of Theory and Practice in Education. 2(2), 113-118. Retrieved from http://eku.comu.edu.tr/index/2/2/etopkaya.pdf

\section{Copyrights}

Copyright for this article is retained by the author(s), with first publication rights granted to the journal.

This is an open-access article distributed under the terms and conditions of the Creative Commons Attribution license which permits unrestricted use, distribution, and reproduction in any medium, provided the original work is properly cited. 